\title{
Biodiesel Production using Trans-Esterification Process and Investigation of Fuel Properties: A Review Study
}

\author{
Hossein Esmaeili* and Rauf Foroutan \\ Department of chemical engineering, Bushehr branch, Islamic Azad University, Bushehr, Iran
}

Submission: April 01,2017 ; Published: June 07, 2017

*Corresponding author: Hossein Esmaeili, Department of chemical engineering, Bushehr branch, Islamic Azad University, Bushehr, Iran, Tel: +989179885692; Email: esmaeili.hossein@iaubushehr.ac.ir, esmaeili.hossein@gmail.com

\begin{abstract}
Biodiesel is a renewable fuel that, due to increasing environmental pollution and global warming caused by fossil fuels, its production is increased. Nowadays, low prices renewable sources like waste edible oil which has been disposed from restaurants, is used to produce the biodiesel. One of methods for biodiesel production is trans-Esterification. In the trans-Esterification process, the reaction takes place in the presence of catalysts such as alkaline, acidic and enzymatic catalysts. Finally, properties of biodiesel such as flash point, kinematic viscosity, density, cloud point and pour point will obtain based on the international standard ASTM D6751 and the properties are compared with diesel fuel.
\end{abstract}

Keywords: Biodiesel production; Trans-esterification; Catalyst; Fuel properties; ASTM D6751

\section{Introduction}

Fossil fuels such as oil, coal and natural gas, supply the major part of the world's energy. Fossil fuel resources are limited and will end in the near future [1]. After the oil crisis in 1970 , extensive researches were conducted on the alternative, renewable, easily accessible and cleaner fuels than the fossil fuels for internal combustion engines [2]. Biodiesel is an alter native fuel that can be produced from renewable biological sources such as vegetable oils and animal fats [1]. This fuel is biodegradable, non-toxic and renewable and produces fewer pollutants in compared with the petroleum-derived fuels [3]. Biodiesels produced from vegetable oil sand animal fats have been shown to have higher viscosity than diesel and can be used as fuel in diesel engines without significant changes [4-6].

Biodiesel containing greater amounts of oxygen compared to diesel and its usage in diesel engines has shown that the amount of smoke, noise, carbon monoxide, sulfur compounds, poly-aromatic hydrocarbons is fewer in comparison with the fossil fuels [7,8]. Various ways such as micro emulsion, dilution and trans-esterificationcan be applied to produce biodiesel, which the latter method is mainly used to produce biodiesel [9]. In the process of Trans-Esterification, the chemical reaction occurs between free fatty acids and the alcohol chains, in which methanol is used as the alcohol because of its low commercial price $[10,11]$. In this process, the reaction takes place in the presence of catalysts such asalkaline [12], acidic [13] and enzymatic catalysts [14]. In biodiesel production, the cost of raw material used is more than $70 \%$ of the total cost of the process and the product $[15,16]$. To produce biodiesel, crude vegetable oils are mainly used which in return, increase operating costs and the price of the final product. Thus, to minimize the total cost, using of low-value resources of triglyceride oils such as animal fats and food waste oils is taken into consideration [17].

To produce biodiesel by trans-Esterification process, oil, catalyst and alcohol (preferably methanol) with different ratios are mixed. After producing the biodiesels, they pour into a separating funnel for 24 hours until the biodiesel and the glycerol phase were separated. After the glycerol phase was separated from the solution, them ethyl ester phase was initially washedwith5\%sulfuric acid solution to dissolve soap and get it out of them ethyl ester phase. After was hingseveral times with5\% acid solution, the desired phase was washed with distilled water for several times at the temperature of 65 ${ }^{\circ} \mathrm{C}$, until it completely was neutralized. The product was then poured into the beaker and about $10 \mathrm{~g}$ of sodium sulfate was added and stirred for 40 minutes to absorb the water contained within the product. The resulting product is filtered through 
the filter paper and vacuum pump to separate sodium sulfate from the solution. Thereafter filtering, the biodiesel was poured into plastic bottles made of polyethylene terephthalate and was stored at room temperature [18].

\section{Characterization of the Produced Biodiesel}

Fuel properties such as viscosity, density, flash point, cloud point, pour point, acid value and Cetane number are analyzed based on the international standards of ASTM D 6751.These properties are defined as follows.

\section{Kinematic Viscosity}

Kinematic viscosity is a critical feature for motor fuel. It plays an important role in the fuel injection, mixing and combustion of fuels [19]. The viscosity of the fuel is effective in softening system. If the fuel viscosity is low, it can't supply effective softening properties to provide a fuel injection system, which in return, lead to increase the erosion and leak of the fuel system. If the fuel viscosity is high, the fuel injection system requires more energy to inject fuel and also the fuel distribution cannot be done well. As a result, the amount of energy production reduces and the exhausted particulate emissions and fumes increases [20]. Therefore, considering the advantages and disadvantages of the fuel kinematic viscosity, viscosity of the produced biodiesel should be in such a manner to prevent reduction of fuel injection and also, to decrease the erosion of injector pump parts and exhausted particulate emissions and fumes. The standard amount of viscosity must be $1.9-6 \mathrm{~mm} 2 / \mathrm{s}$ according to the ASTM D6751.

\section{Flash Point}

The flash point is the temperature at which it can vaporize to form an ignitable mixture in air. Flash point is a very important parameter for biodiesel and other fuels, since this parameter represents the safety, storage and transportation of the fuel. The biodiesel flash point is affected significantly by the amount of methanol in fuel. If the amount of methanol in biodiesel increases for $5 \%$, the flash point for biodiesel is reduced by about $52{ }^{\circ} \mathrm{C}$ [21]. Flash point for fuels derived from oil is $52{ }^{\circ} \mathrm{C}$ while, as the according to ASTM D6751-2standard, flash point is reported to be higher than $132{ }^{\circ} \mathrm{C}$. As reported in many researches, the flash point of biodiesels is reported to be higher than of the ASTM D6751estimated flash point and is in the range of $160{ }^{\circ} \mathrm{C}$ to $200{ }^{\circ} \mathrm{C}$ [22-25].

\section{Pour point}

Pour point is another physical property of the fuels. Pour point of biodiesel is independent of the type of catalyst and the reaction conditions. The Pour point of biodiesel depends on the amount of saturated fatty acids in the oil [26]. Pour point is one of the fuel flow characteristics at different temperatures. This feature limits the use of biodiesel in a different climate and different geographical conditions. The pour point of a liquid is the temperature at which it becomes semi solid and loses its flow characteristics and subsequently, it leads fuel system to be in trouble. Using of a fuel with a temperature lower than its pour point leads to reduce the engine performance.

\section{Cloud point}

Cloud point is one the temperature-dependent parameters that affect the use of biodiesel in different geographical and climatic conditions. The permissible limit for cloud point isn't reported according to the ASTM D6751 standard and this parameter should be determined for each special climatic conditions of each region, separately. But in some recent studies, the cloud point of the biodiesel produced in accordance with EN ISO 3016 standard has been reported and this parameter varies for different produced biodiesels and is in the range of -20 to $284{ }^{\circ} \mathrm{C}$ [27].

\section{Density}

Biodiesel is a fuel that is made of long hydrocarbon chains and thus, by increasing the amount of biodiesel blended with diesel, the density of the samples increases [28].The relative density of the produced fuel plays a significant role in the fuel injection by the fuel injection system. When the density of the fuel is high, the fuel delivers by the fuel injection system, slowly [29].The standard amount of density must be $860-900 \mathrm{~kg} / \mathrm{m}^{3}$ according to the EN 14214.

\section{Conclusion}

In recent years, due to raising world oil prices, increasing environmental pollution caused by the burning of fossil fuels, increasing the world population and their demands for energy, biodiesels became more attractive than past for many governments. In biodiesel production, about $70 \%$ of the production cost is for preparing the primary resources. Therefore, to decrease the final cost of the biodiesel production, using of low cost oil waste and fat resources is suggested.

\section{Acknowledgment}

The authors are grateful to the Islamic Azad University of Bushehr for supporting this research.

\section{Conflict of Interest}

Author has declared that no any economic interest or any conflict of interest exists.

\section{References}

1. Ramos MJ, Fernández CM, Casas A, Rodríguez L, Pérez Á, et al. (2009) Influence of fatty acid composition of raw materials on biodiesel properties. Bioresour Technol 100(1): 261-268.

2. Canakci M (2007) Combustion characteristics of a turbocharged DI compression ignition engine fueled with petroleum diesel fuels and biodiesel. Bioresour Technol 98(6): 1167-1175.

3. Sdrula N (2010) A study using classical or membrane separation in thebiodiesel process. Desalination 250: 1070-1072. 
4. Meher LC, Dharmagadda VSS, Naik SN (2006) Optimization of alkalicatalyzed transesterification of Pongamia pinnata oil for production of biodiesel. Bioresour Technol 97(12): 1392-1397.

5. Usta N (2005) Use of tobacco seed oil methyl ester in a turbocharged indirect injection? Diesel engine. Biomass and Bio energy 28: 77-86.

6. Kalligeros S, Zannikos F, Stournas S, Lois E, Anastopoulos G, et al. (2003) An investigation of using biodiesel/marine diesel blends on the performance of a stationary diesel engine. Biomass and BioEnergy 24: 141-149.

7. Zullaikah S, Lai CC, Vali SR, Ju YH (2005) A two-step acid-catalyzed process for the production of biodiesel from rice bran oil. Bioresour Technol 96(17): 1889-1896.

8. Bhatti HN, Hanif MA, Qasim M, Rehman A (2008) Biodiesel production from waste tallow. Fuel 87: 2961-2966.

9. Diego TD, Manjón A, Lozano P, Iborra JL (2011) a recyclable enzymatic biodiesel production process in ionic liquids. Bioresour Technol 102(10): 6336-6339.

10. Wang Y, Ou S, Liu P, Xue F, Tang S, et al. (2006) Comparison of two different processes to synthesize biodiesel by waste cooking oil Journal of Molecular Catalysis A: Chemical 252: 107-112.

11. Demirbas A (2003) Comparison of two different processes to synthesize biodiesel by waste cooking oil. Energy Conversion and Management 44: 2093-2109.

12. Ramezani K, Rowshanzamir S, Eikani MH (2010) Castor oil transesterification reaction: A kinetic study and optimization of parameters. Energy 35(10): 4142-4148.

13. Tiwari AK, Kumar A, Raheman H (2007) Biodiesel production from jatropha oil (Jatropha curcas) with high free fatty acids: An optimized process. Biomass and BioEnergy 31: 569-575.

14. TamalampudiS, Talukder MR, HamaSh, NumataT, Kondo A, et al. (2008) enzymatic production of biodiesel from Jatropha oil: A comparative study of immobilized-whole cell and commercial lipases as a biocatalyst. Biochemical Engineering Journal 39: 185-189.

15. Phan AN, Phan TM (2008) Biodiesel production from waste cooking oils. Fuel 87: 3490-3496.

16. Meng X, Chen G, Wang Y (2008) Biodiesel production from waste cooking oil via alkali catalyst and its engine test. Fuel Processing Technology 89: 851-857.

17. Tan KT, Lee KT, Mohamed AR (2011) Potential of waste palm cooking oil for catalyst-free biodiesel production. Energy 36(4): 2085-2088.
18. Esmaeili H, Foroutan R, Zareas IM (2016) producing the Biodiesel by Combination of Olive Oil and Chicken Fat using Alkaline Catalysts. Advances in Bioresearch 7(1): 44-52.

19. Canakci M, Sanli H (2008) Biodiesel production from various feed stocks and their effects on the fuel properties. J Ind Microbiol Biotechnol 35(5): 431-441.

20. Rao P (2011) Experimental investigations on the influence of properties of jatropha biodiesel on performance, combustion, and emission characteristics of a DI-CI engine. World Acad Sci Eng Technol, p. 75.

21. Rabu RA, Janajreh I, Honnery D (2013) Transesterification of waste cooking oil: Process optimization and conversion rate evaluation. Energy Conversion and Management 65: 764-769.

22. Uzun BB, Kılıç M, Özbay N, Pütün AE, Pütün E, et al. (2012) Biodiesel production from waste frying oils: Optimization of reaction parameters and determination of fuel properties. Energy 44: 347-351.

23. Refaat AA, Attia NK, Sibak HA, ElSheltawy ST, Eldiwani GI, et al. (2008) Production optimization and quality assessment of Biodiesel from waste vegetable oil. International Journal of Environmental Science Technology 5(1): 75-82

24. Dias JM, Alvim-Ferraz MCM, Almeida MF (2008) Comparison of the performance of different homogeneous alkali catalysts during transesterification of waste and virgin oils and evaluation of biodiesel quality. Fuel 87: 3572-3578.

25. Felizardo P, Correia MJN, Raposo I, Mendes JF, Berkemeier R, et al. (2006)Production of biodiesel from waste frying oils. Waste Management 26(5): 487-494.

26. Alptekin E, Canakci M (2011) Optimization of transesterification for methyl ester production from chicken fat. Fuel 90: 2630-2638.

27. Diya'uddeen BH, Abdul Aziz AR, Daud WMAW, Chakrabarti MH (2012) Performance evaluation of biodiesel from used domestic waste oils: A review. Process Safety and Environmental Protection 90(3):164-179.

28. Felizardo P, Correia MJN, Raposo I, Mendes JF, Berkemeier R, et al (2006) Production of biodiesel from waste frying oils. Waste Manag 26(5): 487-494.

29. Altun Ş, Yaşar F, Öner C (2010) The fuel properties of methyl esters produced from canola oil- animal goat blends by base catalyzed transesterification. International Journal of Engineering Research and Development 2(2): 2-5.

\section{Your next submission with Juniper Publishers will reach you the below assets}

- Quality Editorial service

- Swift Peer Review

- Reprints availability

- E-prints Service

- Manuscript Podcast for convenient understanding

- Global attainment for your research

- Manuscript accessibility in different formats

( Pdf, E-pub, Full Text, Audio)

- Unceasing customer service

Track the below URL for one-step submission https://juniperpublishers.com/online-submission.php 